\title{
Integral Roles for Integrins in $\gamma \delta$ T Cell Function
}

\author{
Gabrielle M. Siegers* \\ Experimental Oncology, University of Alberta, Edmonton, AB, Canada
}

Integrins are adhesion receptors on the cell surface that enable cells to respond to their environment. Most integrins are heterodimers, comprising $\alpha$ and $\beta$ type I transmembrane glycoprotein chains with large extracellular domains and short cytoplasmic tails. Integrins deliver signals through multiprotein complexes at the cell surface, which interact with cytoskeletal and signaling proteins to influence gene expression, cell proliferation, morphology, and migration. Integrin expression on $\gamma \delta T$ cells $(\gamma \delta \mathrm{Tc})$ has not been systematically investigated; however, reports in the literature dating back to the early 1990s reveal an understated role for integrins in $\gamma \delta$ Tc function. Over the years, integrins have been investigated on resting and/or activated peripheral blood-derived

OPEN ACCESS

Edited by:

Pierre Vantourout, King's College London, United Kingdom

Reviewed by: Vicky Morrison, University of Glasgow, United Kingdom

Wendy L. Havran, The Scripps Research Institute, United States

C. David Pauza, American Gene Technologies International Inc., United States

${ }^{*}$ Correspondence: Gabrielle M. Siegers siegers@ualberta.ca

Specialty section: This article was submitted to T Cell Biology, a section of the journal

Frontiers in Immunology

Received: 15 January 2018 Accepted: 28 February 2018

Published: 13 March 2018

Citation:

Siegers GM (2018) Integral Roles for Integrins in $\gamma \delta T$ Cell Function.

Front. Immunol. 9:521. doi: 10.3389/fimmu.2018.00521 polyclonal $\gamma \delta \mathrm{Tc}, \gamma \delta \mathrm{Tc}$ clones, as well as $\gamma \delta \mathrm{T}$ intraepithelial lymphocytes. Differences in integrin expression have been found between $\alpha \beta$ T cells $(\alpha \beta T c)$ and $\gamma \delta$ Tc, as well as between $V \delta 1$ and $V \delta 2 \gamma \delta T$ c. While most studies have focused on human $\gamma \delta T c$, research has also been carried out in mouse and bovine models. Roles attributed to $\gamma \delta$ Tc integrins include adhesion, signaling, activation, migration, tissue localization, tissue retention, cell spreading, cytokine secretion, tumor infiltration, and involvement in tumor cell killing. This review attempts to encompass all reports of integrins expressed on $\gamma \delta$ Tc published prior to December 2017, highlights areas warranting further investigation, and discusses the relevance of integrin expression for $\gamma \delta$ Tc function.

Keywords: gamma delta $\mathrm{T}$ cells, adhesion and signaling molecules, cellular migration, tissue retention, tissue localization, tumor infiltrating lymphocytes, cytotoxicity, cytokine secretion

\section{INTRODUCTION}

Although much was known about integrins on lymphocytes as early as 1990 (1), integrin expression on $\gamma \delta \mathrm{Tc}$ has been only sporadically, and often indirectly, investigated. Considered all together, these reports reveal an understated role for integrins in $\gamma \delta$ Tc function (Table 1).

Integrins are heterodimeric adhesion receptors comprising non-covalently linked $\alpha$ and $\beta$ chains (2). Greek letters indicating chain pairings for $\beta 1$ and cluster of differentiation designations for $\beta 2$ integrins are used throughout this review; cited works may have used alternative nomenclature.

\section{INTEGRIN ACTIVATION AND FUNCTIONS}

Integrins play a role in many cellular functions including development, activation, differentiation, proliferation, mobility, and survival $(1,3)$. Integrins enable two-way communication between cells (cytoskeleton) and their surroundings [extracellular matrix (ECM), other cells]. ECM proteins with which integrins interact include collagen, a structural protein, and adhesion proteins fibronectin (FN) and vitronectin (4). Signaling through integrins can be "inside-out," regulating extracellular interaction between integrins and their ligands, but also "outside-in," influencing actin cytoskeleton 
TABLE 1 | Integrin expression reported on $\gamma \delta$ T cells; cells used were blood-derived unless otherwise indicated.

\begin{tabular}{|c|c|c|c|c|c|c|c|}
\hline & $\alpha$ & $\beta$ & a.k.a & Binds & Function & spp & Reference \\
\hline \multicolumn{8}{|l|}{$\beta 1$} \\
\hline$\alpha 1 \beta 1$ & CD49a & CD29 & VLA-1 & Collagen IV & Extravasation, tumor infiltration, cellular morphology & $\mathrm{H}$ & $(16)$ \\
\hline$\alpha 2 \beta 1$ & CD49b & CD29 & VLA-2 & Collagen & n.d. & $\mathrm{H}$ & $(15)$ \\
\hline \multirow[t]{6}{*}{$\alpha 4 \beta 1$} & CD49d & CD29 & VLA-4 & FN & n.d. & $\mathrm{H}$ & $(15)$ \\
\hline & & & & & Signaling, adhesion & $\mathrm{H}$ & $(17)$ \\
\hline & & & & & Adhesion to endothelial cells & $\mathrm{H}$ & (9) \\
\hline & & & & VCAM-1 & Endothelial layer permeability & $H$ & (29) \\
\hline & & & & & Transendothelial migration? & $\mathrm{H}$ & (30) \\
\hline & & & & & Adhesion to fibroblasts & $\mathrm{H}$ & (49) \\
\hline \multirow[t]{5}{*}{$\alpha 5 \beta 1$} & CD49e & CD29 & VLA-5 & FN & n.d. & $\mathrm{H}$ & $(15)$ \\
\hline & & & & & Signaling, adhesion & $\mathrm{H}$ & $(17)$ \\
\hline & & & & & Transendothelial migration? & $\mathrm{H}$ & (30) \\
\hline & & & & & V反1 activation, localization, retention & $\mathrm{H}$ & (9) \\
\hline & & & & & Adhesion to fibroblasts & $\mathrm{H}$ & $(49)$ \\
\hline$\alpha 6 \beta 1$ & CD49f & CD29 & VLA-6 & & Transendothelial migration & $\mathrm{H}$ & $(30)$ \\
\hline \multicolumn{8}{|l|}{$\beta 2$} \\
\hline \multirow[t]{9}{*}{$\alpha\llcorner\beta 2$} & CD11a & CD18 & LFA-1 & CD54/ICAM-1 & Adhesion to endothelial and epithelial cells, fibroblasts & $\mathrm{H}$ & $(9)$ \\
\hline & & & & & Naive $\alpha \beta$ Tc activation? & $\mathrm{H}$ & (19) \\
\hline & & & & & Endothelial layer permeability & $\mathrm{H}$ & (29) \\
\hline & & & & & Transendothelial migration? & $\mathrm{H}$ & (30) \\
\hline & & & & & Trafficking to infected airways (TB)? & $\mathrm{NHP}$ & (33) \\
\hline & & & & & Adhesion to fibroblasts & $\mathrm{H}$ & $(49)$ \\
\hline & & & & & K562 leukemia cell binding & $\mathrm{H}$ & (54) \\
\hline & & & & & Cytotoxicity against Burkitt Lymphoma, prostate cancer, Daudi B cell lymphoma & $\mathrm{H}$ & $(55-58)$ \\
\hline & & & & & CNS trafficking in EAE? (LN, spleen-derived) & M & $(22)$ \\
\hline \multirow[t]{3}{*}{$\alpha \mathrm{M} \beta 2$} & CD11b & CD18 & Mac-1 & & Naive $\alpha \beta$ Tc activation? & $\mathrm{H}$ & (19) \\
\hline & & & Mo-1 & & Early fetal thymocyte differentiation? & M & (67) \\
\hline & & & & & CNS trafficking in EAE? (LN, spleen-derived) & M & (22) \\
\hline \multirow[t]{3}{*}{$\alpha \times \beta 2$} & CD11c & CD18 & P150,95 & & Naive $\alpha \beta$ Tc activation? & $\mathrm{H}$ & (19) \\
\hline & & & & & Homing, activation, interferon $\gamma$ secretion & $\mathrm{H}$ & (20) \\
\hline & & & & & CNS trafficking in EAE? (LN, spleen-derived) & M & $(22)$ \\
\hline \multirow[t]{5}{*}{$\alpha \mathrm{D} \beta 2$} & CD11d & CD18 & & ICAM-1 & V81 cell spreading? & $\mathrm{H}$ & (25) \\
\hline & & & & VCAM-1 & Inflammatory response? Vס1 tissue retention? & $\mathrm{H}$ & (23) \\
\hline & & & & & Proliferation? & M & (22) \\
\hline & & & & & Early fetal thymocyte differentiation? & M & (67) \\
\hline & & & & & CNS trafficking in EAE? (LN, spleen-derived) & M & (22) \\
\hline \multicolumn{8}{|l|}{$\beta 3$} \\
\hline$\alpha \vee \beta 3$ & $\alpha \vee$ & $\beta 3$ & VNR & RGD sequence & IL-4 production (DETC) & M & $(71)$ \\
\hline \multicolumn{8}{|l|}{$\beta 7$} \\
\hline \multirow[t]{7}{*}{$\alpha E \beta 7$} & CD103 & $\beta 7$ & & E-cadherin & Epithelial retention of $\gamma \delta \mathrm{TC}$ IEL? & $\mathrm{H}$ & (37) \\
\hline & & & & & & M & $(78,79)$ \\
\hline & & & & & Proliferation? IL-9 production? & $\mathrm{H}$ & $(40)$ \\
\hline & & & & & V81 binding SCC & $\mathrm{H}$ & (49) \\
\hline & & & & & V反1 tumor retention? & $\mathrm{H}$ & (49) \\
\hline & & & & & Homing to gut? (mLN, colitis) & M & (80) \\
\hline & & & & & Homing to and retention in gut? & $\mathrm{R}$ & (81) \\
\hline \multirow[t]{4}{*}{$\alpha 4 \beta 7$} & CD49d & $\beta 7$ & & MadCAM & Susceptibility to HIV infection on CCR5+V反2 & $\mathrm{H}$ & (60) \\
\hline & & & & & Homing to gut (TDL, RTE) & M & $(76,80)$ \\
\hline & & & & & Migration to inflamed tissue in allergic reaction & M & (77) \\
\hline & & & & & Migration to tissues & $\mathrm{B}$ & $(7)$ \\
\hline
\end{tabular}

Question marks denote suggested functions that require further validation. a.k.a., also known as; B, bovine; CNS, central nervous system; DETC, dendritic epidermal T cells; EAE, experimental autoimmune encephalitis; ECM, extracellular matrix; FN, fibronectin; H, human; ICAM, intercellular adhesion molecule; IEL, intraepithelial Iymphocyte; IL, interleukin; LFA-1, lymphocyte function-associated antigen-1; LN, lymph node; M, murine; MAdCAM-1, mucosal addressin cell adhesion molecule 1; mLN, mesenteric lymph node; n.d., not determined in this report (with respect to $\gamma \delta$ T cells); NHP, nonhuman primate; ref, reference; RTE, recent thymic emigrant; SCC, squamous cell carcinoma; spp, species; TB, tuberculosis; TDL, thoracic duct lymphocytes; VCAM-1, vascular cell adhesion molecule-1; VLA, very late antigen; VNR, vitronectin receptor.

rearrangement as well as gene expression and transcription of associated proteins, including cytokines, to impact cellular processes $(5,6)$.
Integrins are integral to lymphocyte homing to tissues and migration within tissues; they-together with selectins and their respective ligands-participate in tethering, rolling, and adhesion 
(7). Integrins respond to chemokine signaling arresting migration of lymphocytes and facilitating transmigration into tissues (8). In contrast to other cell types, $\beta 1$ integrins on conventional $\mathrm{T}$ cells require activation for adhesion to occur $(9,10)$. Basal adhesion levels reflect inactive or low-affinity status of integrins; stimulus with 12-O-tetradecanoylphorbol-13-acetate, anti-CD3 or anti-CD2 activates $\beta 1$ integrins, converting them to a highaffinity state without necessitating greater surface expression (10). Such activation dependence is also true for the $\beta 2$ integrin CD11a/CD18 in T cell adhesion and de-adhesion (11). Indeed, several integrins serve as costimulatory molecules in concert with $\mathrm{T}$ cell antigen receptor (TCR) engagement (10, 12-14). Much occurs downstream of integrin-mediated cell adhesion, including phosphorylation of proteins in signaling pathways for cell cycle, cytokine expression, and cytoskeletal remodeling enabling processes such as proliferation and migration $(3,6)$.

Integrins on human $\gamma \delta \mathrm{Tc}$ will first be considered, loosely grouped according to function, and then findings in other species will be discussed. Figure 1 depicts integrins found on $\gamma \delta T c$ and some of their functions.

\section{ADHESION AND SIGNALING}

In $1992, \alpha 4, \beta 1$, and CD18 were identified on human $\mathrm{V} \gamma 9 \gamma \delta \mathrm{Tc}$ derived from stimulated peripheral blood mononuclear cells (PBMCs). While no $\alpha 3, \alpha v$, or $\beta 3$ expression was observed, less than $30 \%$ expressed $\alpha 1, \alpha 2$, or $\alpha 5$ chains. $\mathrm{CD}^{+} \gamma \delta \mathrm{T}$ c clones expressed high $\beta 1$, and consistent $\alpha 4$ and $\alpha 5$ levels. Phorbol 12-myristate 13-acetate (PMA)-induced adhesion via integrin activation; while $\alpha 2 \beta 1$ was required for collagen binding, FN binding relied on both $\alpha 4 \beta 1$ and $\alpha 5 \beta 1$. Most polyclonal $\gamma \delta \mathrm{Tc}$ only expressed $\alpha 4 \beta 1$, whereas individual clones showed variation attributed to extended culturing and selection during cloning (15), corroborating evidence that $\beta 1$ expression on $\mathrm{T}$ cells increases qualitatively and quantitatively over time in culture ( 1 ,
16). Admittedly, these studies used activated $\gamma \delta T c$ and may not have reflected the state of cells in circulation (15).

Expression of $\alpha 4$ and $\alpha 5$ on $\mathrm{CD}^{+}{ }^{+} \mathrm{CD} 4^{-} \mathrm{CD} 8^{-} \gamma \delta \mathrm{Tc}$, and lack of $\alpha 3$ or $\alpha 6$ was confirmed. Activated CD $25^{\text {hi }} \gamma \delta$ Tc bound FN better than resting $\mathrm{CD} 25^{\text {low }} \gamma \delta \mathrm{Tc}$, mediated mostly by $\alpha 4$ and partly by $\alpha 5$. Culturing cells on immobilized anti- $\gamma \delta$ TCR antibodies together with FN enhanced proliferation and increased CD25 expression, suggesting both signaling and adhesion roles for $\alpha 4$ and $\alpha 5$ integrins. While $\gamma \delta \mathrm{Tc}$ adhesion required activation through the TCR, surface levels of $\alpha 4$ and $\alpha 5$ remained unaltered (17). Cytokines such as interleukin (IL)-1 $\beta$ and TNF- $\alpha$ may influence $\gamma \delta$ Tc integrin expression and/or activation (18); this has yet to be explored.

Compared to $\alpha \beta T c$, fresh primary $\gamma \delta \mathrm{Tc}$ were more adhesive ( 2:1 to 4:1) to endothelial cells, fibroblasts, and epithelial cells independent of activation. Both $\alpha \beta \mathrm{Tc}$ and $\gamma \delta \mathrm{Tc}$ required CD11a/ CD18 and $\alpha 4 \beta 1$ to bind endothelial cells, whereas CD11a/ CD18-ICAM-1 interaction facilitated adherence to fibroblasts and epithelial cells. Phorbol dibutyrate treatment of PBMCs and cytokine stimulation of monolayers greatly enhanced $\mathrm{T}$ cell adhesion, correlated with their expression of CD11a/CD18 and $\alpha 4 \beta 1$ (9). CD11a, b, c, and CD18 were detected on isopentenyl pyrophosphate (IPP)-stimulated $\gamma \delta \mathrm{Tc}$, in parallel with markers indicating antigen presenting potential; integrins were likely involved in clustering between $\gamma \delta \mathrm{Tc}$ and naïve $\alpha \beta \mathrm{Tc}$ in an activation capacity, but their role was not directly addressed (19). It would be of interest to determine whether loss of one or more integrins might impact $\gamma \delta \mathrm{Tc}$ antigen presentation.

In healthy women, constitutively high CD11c levels were observed on circulating $\mathrm{CCR}^{-} \mathrm{CD}^{-}$populations co-expressing $\gamma \delta \mathrm{TCR}$ and CD8; cervical $\gamma \delta \mathrm{Tc}(>20 \%)$ also expressed CD11c. $\alpha 1 \beta 1$ and $\alpha 4 \beta 7$ were co-expressed on CD $11 \mathrm{c}^{+} \mathrm{CCR} 7^{-} \mathrm{CD} 4^{-} \mathrm{T}$ cells, of which $\gamma \delta \mathrm{Tc}$ were a part, but unfortunately not specifically analyzed. CD11c expression was associated with $\mathrm{T}$ cell homing and activation, and interferon $\gamma(\mathrm{IFN} \gamma)$ secretion in a fraction of

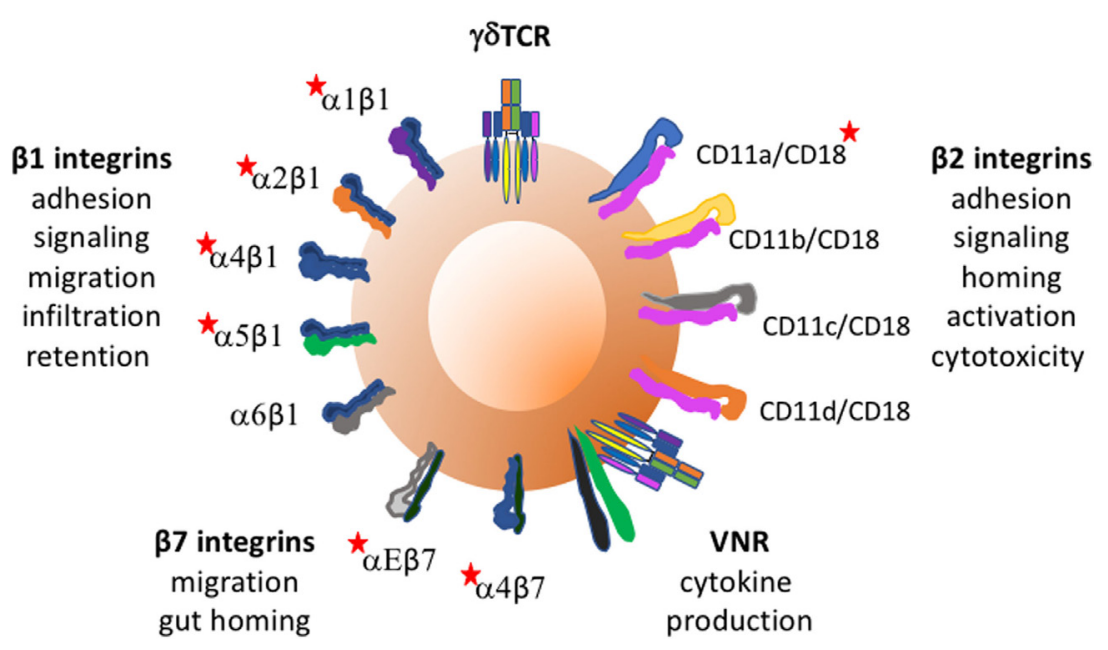

FIGURE 1 | Integrins found on $\gamma \delta$ T cells and some of their functions. Red stars indicate integrins whose expression and/or function on $\gamma \delta T c$ has been reported to require activation. Vitronectin receptor signals through CD3 zeta of the TCR. 
(E)-4-hydroxy-3-methyl-but-2-enyl pyrophosphate-stimulated $\gamma \delta \mathrm{Tc}(20)$.

CD11d, first described in 1995 (21), has now been identified on both murine (22) and human $\gamma \delta \mathrm{Tc}(23)$. CD11d/CD18 binds vascular cell adhesion molecule (VCAM-)1 (24) and intercellular adhesion molecule (ICAM-)3 (21). V81 clones cultured on anti-ICAM-3 plates in the presence of IL-2 underwent spreading; however, the participating receptor on $\gamma \delta \mathrm{Tc}$ had not yet been identified (25). Since ICAM-3 is a CD11d ligand, and CD11d is highly expressed on V $\delta 1 \gamma \delta \mathrm{Tc}$ (23), it was likely CD11d-ICAM-3 interaction mediating this response. ICAM-3 may play a role in inflammatory response initiation, potentially aiding in such processes as antigen presentation and cytotoxicity (26). ICAM-3 on neutrophils participates in IFN $\gamma$ production but not cytotoxicity of NK cells (27) and has some predictive value in perioperative systemic inflammatory response syndrome (28). Thus, CD11d on $\gamma \delta \mathrm{Tc}$ may play a role in inflammation, but this requires further investigation.

\section{TRANSENDOTHELIAL MIGRATION}

In the first report investigating mechanisms by which $\gamma \delta \mathrm{Tc}$ cross the endothelium to migrate into inflamed tissue from the circulation, CD11a/CD18 and $\alpha 4 \beta 1$ on $\gamma \delta$ Tc bound to endothelial cell ligands CD54/ICAM-1 and VCAM-1, respectively, increasing endothelial cell permeability. While cytotoxicity of $\gamma \delta \mathrm{Tc}$ clones to endothelial cells surely contributed to endothelial layer permeability, it was thought unlikely to occur with autologous cells in vivo (29).

An immunophenotyping study showed that $\gamma \delta \mathrm{Tc}$ had greater transendothelial migratory capacity than $\alpha \beta \mathrm{Tc}$ (30), explaining $\gamma \delta \mathrm{Tc}$ enrichment in chronic inflammation $(31,32)$, attributed to CD11a/CD18 expression, and increased $\alpha 4, \alpha 5$, and $\alpha 6 \beta 1$ integrin density on migrating compared to non-migrating T cells; blocking assays were not performed to confirm functional relevance here (30). While CD11d expression on PBMC-derived $\gamma \delta \mathrm{Tc}$ was higher compared to $\alpha \beta$ Tc (freshly isolated or expanded), their migratory ability was not compared (23). In a non-human primate tuberculosis model, adoptively transferred V 22 cells trafficking to infected airways expressed CD11a/CD18 (33). In contrast, increased numbers of peripheral $\gamma \delta \mathrm{Tc}$ expressing reduced $\mathrm{CD} 18$ levels were identified in patients suffering acute psoriasis, suggesting a role in disease pathogenesis (34).

\section{INTEGRINS ON V 81 VERSUS V $\delta 2$ DIRECTING LOCALIZATION AND TISSUE RETENTION}

Integrins likely play a role in the tissue specificity of $\gamma \delta$ Tc subsets. In Galéa's study, V $\delta 1$ and V $\delta 2$ migrated similarly, suggesting that V $\delta 1$ tissue accumulation relates to their retention rather than migratory abilities (30). Indeed, higher CD11d expression on V $\delta 1$ compared to V 22 cells may also account for preferential $\mathrm{V} \delta 1$ retention (23), as well as V $\delta 1$ prevalence in large intestinal mucosal epithelium (35) and conditions such as rheumatoid arthritis $(31,32,36)$.

An E-cadherin binding integrin associated with epithelial retention, $\alpha E \beta 7$ (CD103), was found on human $\gamma \delta \mathrm{Tc}$ intraepithelial lymphocytes (IELs). While peripheral blood $\mathrm{T}$ cells did not express much $\alpha \mathrm{E} \beta 7$ the authors posited its upregulation after $\mathrm{T}$ cells extravasate in the lamina propria, since $\alpha E \beta 7$ expression positively correlated with nearer proximity to epithelium (37). IL-2 and phytohemagglutinin (PHA) stimulation activated $\alpha \mathrm{E} \beta 7$ on cultured $\mathrm{CD} 4^{+} \mathrm{CD} 8^{+}$IEL, and TCR crosslinking enhanced $\alpha E \beta 7$-E-cadherin avidity (38). On $\alpha \beta \mathrm{Tc}$, this transforming growth factor $\beta$ (TGF- $\beta$ )-induced integrin is associated with pro- and anti-inflammatory conditions, tissue retention, and both cytotoxic and regulatory $\mathrm{T}$ lymphocyte tumor infiltration and function, expertly reviewed in Ref. (39). Peters and colleagues noted upregulation of ITGAE, the gene encoding $\alpha E \beta 7$, and corresponding surface expression on expanded V 22 cells treated with TGF- $\beta$ and IL-15 correlating with enhanced proliferation and IL-9 production (40).

Subset variation exists for $\alpha 5 \beta 1$, with V $\delta 1$ expressing more than $\mathrm{V} \delta 2$, providing an explanation for previous reports of low $\alpha 5 \beta 1$ expression in studies focusing on V $\delta 2$ cells. High $\alpha 5 \beta 1$ expression accounted for increased V $\delta 1$ binding to $\mathrm{FN}$, potentially reflecting V $\delta 1$ adhesion to fibroblasts in vivo, and the importance of this interaction for V $\delta 1$ activation and localization (9). During inflammation, mucosal epithelial cells display increased FN levels (41), which may increase V $\delta 1$ retention. Similar ICAM-1 and VCAM-1-mediated binding of V $\delta 1$ and V $\delta 2$ cells could be explained by their comparable expression of CD11a/CD18 and $\alpha 4 \beta 1$ (9). Thus, $\gamma \delta$ Tc tissue recruitment may be achieved through CD11a/CD18 and $\alpha 4 \beta 1$ binding to endothelial cell ligands, and cells retained in tissue via CD11a/CD18 and $\alpha 5 \beta 1$ interactions with epithelial cell-, fibroblast-, and ECM ligands (9).

\section{TUMOR INFILTRATION}

Increased $\alpha 1 \beta 1$ expression may facilitate $\gamma \delta \mathrm{Tc}$ migration out of vessels and infiltration into tumors (16). A known receptor for the basement membrane protein collagen IV, $\alpha 1 \beta 1$ has been observed on IL-2-activated $\mathrm{T}$ cells invading tumors (42-47). While resting peripheral blood $\mathrm{T}$ cells expressed little $\alpha 1 \beta 1$, its expression increased over time in culture; $\gamma \delta$ Tc clones expressed higher $\alpha 1 \beta 1$ than polyclonal T cells (16), corroborating observed $\alpha 1 \beta 1$ expression on long-term activated $\mathrm{T}$ cells (48). Anti- $\alpha 1 \beta 1$ inhibited $\mathrm{CD}^{+} \gamma \delta \mathrm{Tc}$ interaction with collagen IV, but not FN or collagen $\mathrm{I}$, in a concentration-dependent manner. Cellular morphology was impacted, as $\mathrm{Mg}^{2+}$ cation-dependent spreading of long-term cultured CD $8^{+} \alpha 1 \beta 1^{\text {high }} \alpha \beta$ Tc or $\gamma \delta$ Tc on collagen IV-coated slides was inhibited by anti- $\alpha 1 \beta 1$ antibodies (16).

Compared to $\alpha \beta \mathrm{Tc}, \gamma \delta \mathrm{Tc}$ derived from patient blood bound squamous carcinoma (SCC) and fibroblast cells more tightly (49), confirming previous results (9). While CD11a/CD18 played a role in both cases, SCC binding was mediated via L-selectin and CD44v6; fibroblast binding was achieved though $\alpha 4 \beta 1$ and $\alpha 5 \beta 1$ (49).

V81 predominance has been reported in tumor infiltrating lymphocytes from lung (50), colon (51), renal carcinoma (52), and esophageal tumors (49). Preferential extravasation, infiltration, and retention of V $\delta 1$ cells in esophageal tumors was attributed to higher expression and a greater variety of integrins such as CD11a/CD 18, $\alpha 4 \beta 1, \alpha 5 \beta 1$, and $\alpha E \beta 7$ on V 81 compared to

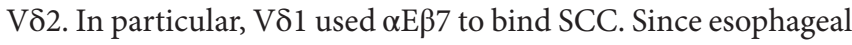


tumors also express E-cadherin, $\alpha \mathrm{E} \beta 7$ expression may provide a mechanism of lymphocyte retention in tumors (49).

\section{CYTOTOXICITY}

CD11a/CD18 facilitates effector-target cell conjugation (53). This interaction, integral to $\gamma \delta \mathrm{Tc}$ cytotoxicity, has been confirmed in binding assays with K562 leukemia (54), and blocking assays with Burkitt Lymphoma (55), prostate cancer (56, 57), and Daudi B cell lymphoma cells (58). We have observed significant $\gamma \delta \mathrm{Tc}$ apoptosis induced by anti- $\gamma \delta \mathrm{TCR}$ (59) antibodies; thus, this may also occur with antibodies blocking CD18 and should be considered when designing controls and interpreting results from blocking assays using such antibodies. Activation of $\alpha \beta T C R$ changes CD11a/CD18 avidity from low to high transiently, to allow adhesion, but then also de-adhesion of T cells, promoting continued serial killing (11). If this holds true for the $\gamma \delta T C R$, then this mechanism greatly contributes to $\gamma \delta \mathrm{Tc}$ cytotoxicity and could be therapeutically relevant.

\section{SUSCEPTIBILITY TO VIRAL INFECTION}

In the absence of CD4, high $\alpha 4$ and $\beta 7$ levels on IPP-expanded V82 cells formed a complex with high levels of CCR5 (fivefold higher than $\alpha \beta \mathrm{Tc}$ ); this inferred HIV envelope glycoprotein susceptibility resulting in $\mathrm{CD}^{-} \mathrm{V} \delta 2$ cells' demise (60). While V $\delta 1$ express as much $\alpha 4 \beta 7$ as V $\delta 2$, they do not express CCR5, thus rendering V81 immune to HIV-envelope-mediated killing (61).

\section{IMMUNOLOGICAL MEMORY}

CD11b (complement receptor 3, Mac-1) expression on peripheral blood $\mathrm{T}$ cells increased with age, leveling out later in life. $\gamma \delta \mathrm{Tc}$ expressed more CD11b than $\alpha \beta$ Tc across all ages; and while not shown, CD11b was thought important for migration to spleen and liver, and to indicate antigen-specific memory T cells (62). Later studies suggested roles associated with $\mathrm{T}$ cell immunoregulation, proliferation, and homing $(63,64)$, but the significance of $\mathrm{CD} 11 \mathrm{~b}$ on human $\gamma \delta \mathrm{Tc}$ remains unknown. Increased $\alpha \beta \mathrm{Tc}$ integrin levels and adherence have been associated with memory $\mathrm{CD}^{+} \mathrm{T}$ cells $(10,65)$, but the only study addressing this with respect to $\gamma \delta \mathrm{Tc}$ equated $\mathrm{V} \delta 1$ with naïve and $\mathrm{V} \delta 2$ with memory cells, then compared V $\delta 1$ to V $\delta 2$ expression of CD11a, $\alpha 4 \beta 1$, and $\alpha 5 \beta 1$ (not CD11b), finding no correlation between adhesion/ integrin levels and maturation (9). A longitudinal study following integrin expression and function during the course of $\gamma \delta \mathrm{Tc}$ maturation would be more appropriate to address this question, keeping in mind the influence of in vitro culture.

\section{OF RODENTS AND RUMINANTS IN HEALTH AND DISEASE...}

\section{$\beta 1$ Integrins}

In mice, $\beta 1$ integrins play an important role in thymocyte differentiation into $\mathrm{CD} 4^{+}$and $\mathrm{CD} 8^{+} \alpha \beta \mathrm{Tc}$; however, their role in $\gamma \delta \mathrm{Tc}$ development remains unknown (66).

\section{$\beta 2$ Integrins}

While not found on thymocytes in adult wild-type mice, transient co-expression of CD11b and CD11d on fetal thymocytes suggests an important role for $\beta 2$ integrins in early differentiation (67).

In the context of experimental autoimmune encephalitis (EAE), murine $\gamma \delta \mathrm{Tc}$ differentially expressed $\beta 2$ integrins and produced more IFN $\gamma$ and tumor necrosis factor $\alpha$ in lymph nodes, spleen, and spinal cord compared to $\alpha \beta \mathrm{Tc}$ (22). At baseline, most $\gamma \delta$ Tc expressed CD $11 \mathrm{a}, \mathrm{b}$, and d. Both $\gamma \delta \mathrm{Tc}$ frequency and upregulation of $\beta 2$ integrins, including CD11c, were noted after EAE induction; $\gamma \delta$ Tc infiltration of the central nervous system (CNS) followed that of $\alpha \beta \mathrm{Tc}$, but was more rapid (22). Thus, $\beta 2$ integrin expression on $\gamma \delta$ Tc affected their trafficking into the CNS, thereby impacting EAE development kinetics (22). In a follow-up study, EAE disease severity was similar in $\gamma \delta \mathrm{Tc}^{-/-}$mice reconstituted with $\gamma \delta \mathrm{Tc}$ lacking $\mathrm{CD} 11 \mathrm{a}, \mathrm{b}$, or c suggesting that $\beta 2$ integrins were not important for CNS trafficking; however, CD11d was still present on $\gamma \delta \mathrm{Tc}$, pointing to this integrin's potential role in trafficking. CD11a/CD $18^{-/-} \gamma \delta \mathrm{Tc}$ displayed reduced CNS retention and expansion during EAE, suggesting CD11a involvement in both retention and co-stimulation (68). While not specific to $\gamma \delta \mathrm{Tc}$, it is interesting that CD3 expression was reduced in $\mathrm{CD}_{11} \mathrm{~b}^{-/-}$and $\mathrm{CD} 11 \mathrm{~d}^{-/-}$mice compared to wildtype. Furthermore, CD11b and CD11d seem important for proliferation of murine $\mathrm{T}$ cells stimulated with PHA and Concanavalin A or superantigen, but not for their response to PMA (67). Indeed, $\beta 2$ integrin expression seems concomitant with $\mathrm{T}$ cell expansion, in line with observations of increased CD11d expression on human $\gamma \delta$ Tc expanded under higher IL-2 levels (23). In a murine spontaneous psoriasis model, reduced $\mathrm{CD} 18$ resulted in loss of $\mathrm{V} \gamma 5^{+}$skin-resident $\gamma \delta \mathrm{Tc}$ and expansion of lymph node derived skin-homing $\mathrm{V} \gamma 4^{+} \gamma \delta \mathrm{Tc}$ contributing to disease initiation and progression. $\mathrm{CD} 18^{\text {low }} \gamma \delta \mathrm{Tc}$ expressed higher IL-7R $\alpha$ levels and increased IL-7-induced proliferation generating inflammatory memory $\mathrm{CD} 44^{+} \mathrm{CD} 27^{-}$capable of IL-17 production (34). Adoptive transfer experiments confirmed that low levels of CD18 did not impair $\gamma \delta$ Tc trafficking to the skin in healthy mice (34). Itgax, the gene encoding integrin CD11c, is common to $\gamma \delta \mathrm{Tc}$ and NK cells, yet, differentiates $\gamma \delta \mathrm{Tc}$ from iNKT and $\alpha \beta$ Tc in the mouse (69). Murine CD11c was identified on $\gamma \delta$ Tc in the blood and genital tract, most predominantly on $\gamma \delta \mathrm{Tc}$ co-expressing NK1.1. Vaginal Chlamydia infection expanded circulating CD $11 c^{+} \gamma \delta \mathrm{Tc}(20)$.

\section{The Vitronectin Receptor (VNR)}

An integrin later identified as the VNR, or $\alpha v \beta 3$, was found on murine dendritic epidermal T cell lines (DETC); its expression on splenic T cells was only observed after a minimum of 1 week of stimulation (70). VNR expression was soon further confirmed on autoreactive DETC-derived cell lines $(6,71,72)$. A subset of these $\gamma \delta \mathrm{Tc}(\mathrm{V} \gamma 1.1 / \mathrm{C} \gamma 4-\mathrm{V} \delta 6 / \mathrm{C} \delta 1)$ secreted IL-4 in a VNR-dependent manner (71). In a follow-up report using a $\mathrm{TCR}^{-/-}$hybridoma line transfected with $\mathrm{CD} 3 \zeta$ fusion proteins, VNR- but not TCRengagement by ligand was required in conjunction with $\mathrm{CD} 3 \zeta$ chain signaling for IL-2 production (73). VNR recognizes the adhesive peptide sequence RGD in ECM proteins (74). While human $\alpha \beta$ Tc can be induced to express VNR upon stimulation 
with PHA and/or PMA (75), VNR has not been found on polyclonal or clonal human $\gamma \delta \mathrm{Tc}(15)$.

\section{$\alpha 4 \beta 7$ and $\alpha E \beta 7$}

High levels of $\alpha 4 \beta 7$ were associated with gut-tropism of murine $\gamma \delta \mathrm{Tc}$ trafficking from adult thymus to the small intestine epithelium, whereupon reaching their destination, $\alpha 4 \beta 7$ was subsequently downregulated, through interaction with its counterreceptor mucosal addressin cell adhesion molecule 1 (MadCAM) on the lamina propria (76). In a model of allergic reaction, IL-17 $\gamma \delta$ Tc expressed $\alpha 4 \beta 7$ that enabled their mobilization by CCL25 in inflamed tissue, which in turn modulated IL-17 levels (77). Blocking $\alpha 4 \beta 7$ in vivo prevented the migration of IL- $17^{+} \gamma \delta \mathrm{Tc}$ but not $\alpha \beta$ Tc into mouse pleura, and also blocked transmigration of $\gamma \delta$ Tc across VCAM-1- and MadCAM-1-expressing endothelium toward CCL25 or cell-free pleural washes from mice in whom an allergic reaction had been induced (77). Bovine peripheral bloodderived $C D 8^{+} \gamma \delta \mathrm{Tc}$ accumulated in MAdCAM-1-expressing tissues in a dose-dependent manner. $\mathrm{CD} 8^{+} \gamma \delta$ Tc expressed 1.5 -fold more $\alpha 4 \beta 7$ than $\mathrm{CD}^{-} \gamma \delta \mathrm{Tc}$ but similar $\beta_{1}$ and $\beta_{2}$ levels. While adding CXCL12 increased MAdCAM binding of all $\gamma \delta$ Tc, CCL2 1 activated integrins and increased $\mathrm{CD}^{+} \gamma \delta \mathrm{Tc}$ binding to recombinant MAdCAM1 more so than $\mathrm{CD}^{-} \gamma \delta \mathrm{Tc}$. Circulating human $\mathrm{CD}^{-}$and $\mathrm{CD}^{+} \gamma \delta \mathrm{Tc}$ migrated similarly in response to CCL21, and expressed comparable $\alpha 4 \beta 7$; this species-specific discrepancy was attributed to CD8 chain usage differences in humans $(\alpha \alpha)$ versus cows $(\alpha \beta)(7)$.

Prevalence of "inflammatory" $\gamma \delta \mathrm{Tc}(\mathrm{i} \gamma \delta \mathrm{Tc})$ co-expressing high levels of gut-homing $\alpha 4 \beta 7$ and $\alpha E \beta 7$ correlated with disease severity in both spontaneous and induced murine colitis models. Cytotoxicity, cytokine production, and NK cell receptor genes were upregulated on $\mathrm{i} \gamma \delta \mathrm{Tc}$ compared to other $\gamma \delta \mathrm{Tc}$ subsets (expressing $\alpha 4 \beta 7$ or $\alpha E \beta 7$ ) isolated from mesenteric lymph nodes in induced colitis, suggesting profound functional relevance of integrin co-expression on these cells (78).

In $\alpha E \beta 7$-knockout mice, $\gamma \delta$ Tc IEL migration within the intraepithelial compartment was enhanced (79) and remained so when challenged with Salmonella typhimurium or Toxoplasma gondii, drastically reducing pathogen translocation and emphasizing the ability of $\alpha E \beta 7$ to limit $\gamma \delta$ Tc IEL migration and impact host defense against infection (80). In a study on suckling Lewis

\section{REFERENCES}

1. Hemler ME. VLA proteins in the integrin family: structures, functions, and their role on leukocytes. Annu Rev Immunol (1990) 8:365-400. doi:10.1146/ annurev.iy.08.040190.002053

2. Stewart M, Thiel M, Hogg N. Leukocyte integrins. Curr Opin Cell Biol (1995) 7:690-6. doi:10.1016/0955-0674(95)80111-1

3. Streuli CH. Integrins as architects of cell behavior. Mol Biol Cell (2016) 27:2885-8. doi:10.1091/mbc.E15-06-0369

4. Derya M, Yilmaz I, Aytekin M. The role of extracellular matrix in lung diseases. Biol Med (2014) 6:1-8. doi:10.4172/0974-8369.1000200

5. Lub M, van Kooyk Y, Figdor CG. Ins and outs of LFA-1. Immunol Today (1995) 16:479-83. doi:10.1016/0167-5699(95)80031-X

6. Halvorson MJ, Coligan JE, Sturmhofel K. The vitronectin receptor (alpha V beta 3 ) as an example for the role of integrins in T lymphocyte stimulation. Immunol Res (1996) 15:16-29. doi:10.1007/BF02918281 rats, probiotics significantly increased both CD62L-positive and negative $\mathrm{CD}^{-}{ }^{-} \mathrm{CD} 8^{-} \mathrm{T}$ cells expressing $\alpha \mathrm{E} \beta 7$ in mesenteric lymph nodes; in IEL, significantly increased CD62L- $\alpha E \beta 7$-expressing $\mathrm{CD}^{-} \mathrm{CD}^{-}$cells were observed, hypothesized to result from enhanced homing and retention, respectively (81).

\section{CONCLUDING REMARKS}

T cells use classical cell biological pathways in new ways (82). Thus, understanding integrin functions on other cell types, including $\alpha \beta \mathrm{T} c$, suggests but does not dictate their roles on $\gamma \delta \mathrm{Tc}$. Some roles suspected in human $\gamma \delta \mathrm{Tc}$ have been confirmed in other species, whereas interspecies variation also exists. Some integrin functions are expected and others surprising, such as HIV-induced V $\delta 2$ demise enabled by $\alpha 4 \beta 7$ complexed with CCR5 (60). This review describes the tip of the iceberg with respect to integrins on $\gamma \delta \mathrm{Tc}$; some have yet to be explored at all, and others are worthy of further study. Understanding integrin contributions to $\gamma \delta \mathrm{Tc}$ activation, proliferation, and cytotoxicity could inform better expansion protocols and improve $\gamma \delta \mathrm{Tc}$ immunotherapy for a variety of indications. We have much to learn about integrin involvement in the myriad functions of these fascinating cells.

\section{AUTHOR CONTRIBUTIONS}

GS reviewed the literature, wrote the manuscript, and designed both the table and the figure.

\section{ACKNOWLEDGMENTS}

Special thanks to Dr. Gregory Dekaban, who introduced me to the exciting world of integrins, and Dr. Lynne-Marie Postovit, for continued support. Thanks to Indrani Dutta for critical reading of the manuscript.

\section{FUNDING}

This work has been supported by the London Regional Cancer Program, London, ON (Translational Breast Cancer Postdoctoral award) and the Cancer Research Society.

7. Wilson E, Hedges JF, Butcher EC, Briskin M, Jutila MA. Bovine gamma delta T cell subsets express distinct patterns of chemokine responsiveness and adhesion molecules: a mechanism for tissue-specific gamma delta T cell subset accumulation. J Immunol (2002) 169:4970-5. doi:10.4049/jimmunol.169.9.4970

8. Campbell JJ, Hedrick J, Zlotnik A, Siani MA, Thompson DA, Butcher EC. Chemokines and the arrest of lymphocytes rolling under flow conditions. Science (1998) 279:381-4. doi:10.1126/science.279.5349.381

9. Nakajima S, Roswit WT, Look DC, Holtzman MJ. A hierarchy for integrin expression and adhesiveness among $\mathrm{T}$ cell subsets that is linked to TCR gene usage and emphasizes $\mathrm{V}$ delta $1+$ gamma delta $\mathrm{T}$ cell adherence and tissue retention. J Immunol (1995) 155:1117-31.

10. Shimizu Y, Van Seventer GA, Horgan KJ, Shaw S. Regulated expression and binding of three VLA (beta 1) integrin receptors on T cells. Nature (1990) 345:250-3. doi:10.1038/345250a0

11. Dustin ML, Springer TA. T-cell receptor cross-linking transiently stimulates adhesiveness through LFA-1. Nature (1989) 341:619-24. doi:10.1038/341619a0 
12. Matsuyama T, Yamada A, Kay J, Yamada KM, Akiyama SK, Schlossman SF, et al. Activation of CD4 cells by fibronectin and anti-CD3 antibody. A synergistic effect mediated by the VLA-5 fibronectin receptor complex. J Exp Med (1989) 170:1133-48. doi:10.1084/jem.170.4.1133

13. Yamada A, Nikaido T, Nojima Y, Schlossman SF, Morimoto C. Activation of human CD4 T lymphocytes. Interaction of fibronectin with VLA-5 receptor on CD4 cells induces the AP-1 transcription factor. J Immunol (1991) 146:53-6.

14. Damle NK, Aruffo A. Vascular cell adhesion molecule 1 induces T-cell antigen receptor-dependent activation of CD4+T lymphocytes. Proc Natl Acad Sci U S A (1991) 88:6403-7. doi:10.1073/pnas.88.15.6403

15. Wilkins J, Selin L, Stewart S, Sivananthan K, Stupack D. The interactions of gamma delta $\mathrm{T}$ cells with extracellular matrix: receptor expression and utilization patterns. Scand J Immunol (1992) 36:213-9. doi:10.1111/ j.1365-3083.1992.tb03093.x

16. Bank I, Book M, Ware R. Functional role of VLA-1 (CD49A) in adhesion, cation-dependent spreading, and activation of cultured human T lymphocytes. Cell Immunol (1994) 156:424-37. doi:10.1006/cimm.1994.1187

17. Avdalovic M, Fong D, Formby B. Adhesion and costimulation of proliferative responses of human gamma delta $\mathrm{T}$ cells by interaction of VLA-4 and VLA-5 with fibronectin. Immunol Lett (1993) 35:101-8. doi:10.1016/ 0165-2478(93)90077-F

18. Meager A. Cytokine regulation of cellular adhesion molecule expression in inflammation. Cytokine Growth Factor Rev (1999) 10:27-39. doi:10.1016/ S1359-6101(98)00024-0

19. Brandes M, Willimann K, Moser B. Professional antigen-presentation function by human gammadelta T Cells. Science (2005) 309:264-8. doi:10.1126/ science. 1110267

20. Qualai J, Li LX, Cantero J, Tarrats A, Fernández MA, Sumoy L, et al. Expression of CD11c is associated with unconventional activated T cell subsets with high migratory potential. PLoS One (2016) 11:e0154253. doi:10.1371/journal. pone. 0154253

21. Van der Vieren M, Le Trong H, Wood CL, Moore PF, St John T, Staunton DE, et al. A novel leukointegrin, alpha d beta 2, binds preferentially to ICAM-3. Immunity (1995) 3:683-90. doi:10.1016/1074-7613(95)90058-6

22. Smith SS, Barnum SR. Differential expression of beta 2-integrins and cytokine production between gammadelta and alphabeta $\mathrm{T}$ cells in experimental autoimmune encephalomyelitis. J Leukoc Biol (2008) 83:71-9. doi:10.1189/ jlb.0407263

23. Siegers GM, Barreira CR, Postovit LM, Dekaban GA. CD11d beta2 integrin expression on human NK, B, and gammadelta T cells. J Leukoc Biol (2017) 101:1029-35. doi:10.1189/jlb.3AB0716-326RR

24. Van der Vieren M, Crowe DT, Hoekstra D, Vazeux R, Hoffman PA, Grayson MH, et al. The leukocyte integrin alpha D beta 2 binds VCAM-1: evidence for a binding interface between I domain and VCAM-1. J Immunol (1999) 163:1984-90.

25. Hernandez-Caselles T, Rubio G, Campanero MR, del Pozo MA, Muro M, Sanchez-Madrid F, et al. ICAM-3, the third LFA-1 counterreceptor, is a co-stimulatory molecule for both resting and activated T lymphocytes. Eur J Immunol (1993) 23:2799-806. doi:10.1002/eji.1830231112

26. Knudsen H, Andersen CB, Ladefoged SD. Expression of the intercellular adhesion molecule-3 (ICAM-3) in human renal tissue with relation to kidney transplants and various inflammatory diseases. APMIS (1995) 103:593-6. doi:10.1111/j.1699-0463.1995.tb01411.x

27. Costantini C, Calzetti F, Perbellini O, Micheletti A, Scarponi C, Lonardi S, et al. Human neutrophils interact with both 6-sulfo LacNAc+ DC and NK cells to amplify NK-derived IFN\{gamma\}: role of CD18, ICAM-1, and ICAM-3. Blood (2011) 117:1677-86. doi:10.1182/blood-2010-06-287243

28. Litmathe J, Boeken U, Bohlen G, Gursoy D, Sucker C, Feindt P. Systemic inflammatory response syndrome after extracorporeal circulation: a predictive algorithm for the patient at risk. Hellenic J Cardiol (2011) 52:493-500.

29. Mohagheghpour N, Bermudez LE, Khajavi S, Rivas A. The VLA-4/VCAM-1 molecules participate in gamma delta cell interaction with endothelial cells. Cell Immunol (1992) 143:170-82. doi:10.1016/0008-8749(92)90014-G

30. Galea P, Brezinschek R, Lipsky PE, Oppenheimer-Marks N. Phenotypic characterization of CD4-/alpha beta TCR + and gamma delta TCR+ T cells with a transendothelial migratory capacity. J Immunol (1994) 153:529-42.

31. Brennan FM, Londei M, Jackson AM, Hercend T, Brenner MB, Maini RN, et al. T cells expressing gamma delta chain receptors in rheumatoid arthritis. J Autoimmun (1988) 1:319-26. doi:10.1016/0896-8411(88)90002-9
32. Meliconi R, Pitzalis C, Kingsley GH, Panayi GS. Gamma/delta T cells and their subpopulations in blood and synovial fluid from rheumatoid arthritis and spondyloarthritis. Clin Immunol Immunopathol (1991) 59:165-72. doi:10.1016/0090-1229(91)90090-W

33. Qaqish A, Huang D, Chen CY, Zhang Z, Wang R, Li S, et al. Adoptive transfer of phosphoantigen-specific gammadelta T cell subset attenuates Mycobacterium tuberculosis infection in nonhuman primates. J Immunol (2017) 198:4753-63. doi:10.4049/jimmunol.1602019

34. Gatzka M, Hainzl A, Peters T, Singh K, Tasdogan A, Wlaschek M, et al. Reduction of CD18 promotes expansion of inflammatory gammadelta $\mathrm{T}$ cells collaborating with CD4+ T cells in chronic murine psoriasiform dermatitis. J Immunol (2013) 191(11):5477-88. doi:10.4049/jimmunol.1300976

35. Deusch K, Lüling F, Reich K, Classen M, Wagner H, Pfeffer K. A major fraction of human intraepithelial lymphocytes simultaneously expresses the gamma/ delta T cell receptor, the CD8 accessory molecule and preferentially uses the V delta 1 gene segment. Eur J Immunol (1991) 21:1053-9. doi:10.1002/ eji.1830210429

36. Sioud M, Kjeldsen-Kragh J, Quayle A, Kalvenes C, Waalen K, Førre O, et al. The $\mathrm{V}$ delta gene usage by freshly isolated $\mathrm{T}$ lymphocytes from synovial fluids in rheumatoid synovitis: a preliminary report. Scand J Immunol (1990) 31:415-21. doi:10.1111/j.1365-3083.1990.tb02787.x

37. Farstad IN, Halstensen TS, Lien B, Kilshaw PJ, Lazarovits AI, Brandtzaeg P. Distribution of beta 7 integrins in human intestinal mucosa and organized gut-associated lymphoid tissue. Immunology (1996) 89:227-37. doi:10.104 6/j.1365-2567.1996.d01-727.x

38. Higgins JM, Mandlebrot DA, Shaw SK, Russell GJ, Murphy EA, Chen YT, et al. Direct and regulated interaction of integrin alphaEbeta7 with E-cadherin. J Cell Biol (1998) 140:197-210. doi:10.1083/jcb.140.1.197

39. Hardenberg JB, Braun A, Schon MP. A Yin and Yang in epithelial immunology: the roles of the alphaE(CD103)beta7 integrin in T cells. J Invest Dermatol (2018) 138:23-31. doi:10.1016/j.jid.2017.05.026

40. Peters C, Hasler R, Wesch D, Kabelitz D. Human Vdelta2 T cells are a major source of interleukin-9. Proc Natl Acad Sci U S A (2016) 113:12520-5. doi:10.1073/pnas.1607136113

41. Campbell AM, Chanez P, Vignola AM, Bousquet J, Couret I, Michel FB, et al. Functional characteristics of bronchial epithelium obtained by brushing from asthmatic and normal subjects. Am Rev Respir Dis (1993) 147:529-34. doi:10.1164/ajrccm/147.3.529

42. Chan BM, Wong JG, Rao A, Hemler ME. T cell receptor-dependent, antigen-specific stimulation of a murine $\mathrm{T}$ cell clone induces a transient, VLA protein-mediated binding to extracellular matrix. J Immunol (1991) 147:398-404.

43. Alcocer-Varela J, Aleman-Hoey D, Alarcon-Segovia D. Interleukin-1 and interleukin-6 activities are increased in the cerebrospinal fluid of patients with CNS lupus erythematosus and correlate with local late T-cell activation markers. Lupus (1992) 1:111-7. doi:10.1177/096120339200100209

44. Saltini C, Hemler ME, Crystal RG. T lymphocytes compartmentalized on the epithelial surface of the lower respiratory tract express the very late activation antigen complex VLA-1. Clin Immunol Immunopathol (1988) 46:221-33. doi:10.1016/0090-1229(88)90185-7

45. Choy MY, Richman PI, Horton MA, MacDonald TT. Expression of the VLA family of integrins in human intestine. J Pathol (1990) 160:35-40. doi:10.1002/ path.1711600109

46. Konter U, Kellner I, Hoffmeister B, Sterry W. Induction and upregulation of adhesion receptors in oral and dermal lichen planus. J Oral Pathol Med (1990) 19:459-63. doi:10.1111/j.1600-0714.1990.tb00787.x

47. Hermann GG, Geertsen PF, von der Maase H, Steven K, Andersen C, Hald T, et al. Recombinant interleukin-2 and lymphokine-activated killer cell treatment of advanced bladder cancer: clinical results and immunological effects. Cancer Res (1992) 52:726-33.

48. Hemler ME. Adhesive protein receptors on hematopoietic cells. Immunol Today (1988) 9:109-13. doi:10.1016/0167-5699(88)91280-7

49. Thomas ML, Badwe RA, Deshpande RK, Samant UC, Chiplunkar SV. Role of adhesion molecules in recruitment of Vdeltal $\mathrm{T}$ cells from the peripheral blood to the tumor tissue of esophageal cancer patients. Cancer Immunol Immunother (2001) 50:218-25. doi:10.1007/s002620100190

50. Zocchi MR, Ferrarini M, Rugarli C. Selective lysis of the autologous tumor by delta TCS1+ gamma/delta+ tumor-infiltrating lymphocytes from human lung carcinomas. Eur J Immunol (1990) 20:2685-9. doi:10.1002/ eji.1830201224 
51. Maeurer MJ, Martin D, Walter W, Liu K, Zitvogel L, Halusczcak K, et al. Human intestinal Vdelta1+ lymphocytes recognize tumor cells of epithelial origin. J Exp Med (1996) 183:1681-96. doi:10.1084/jem.183.4.1681

52. Choudhary A, Davodeau F, Moreau A, Peyrat MA, Bonneville M, Jotereau F. Selective lysis of autologous tumor cells by recurrent gamma delta tumor-infiltrating lymphocytes from renal carcinoma. J Immunol (1995) 154:3932-40.

53. Springer TA. Adhesion receptors of the immune system. Nature (1990) 346:425-34. doi:10.1038/346425a 0

54. Arancia G, Malorni W, Iosi F, Zarcone D, Cerruti G, Favre A, et al. Morphological features of cloned lymphocytes expressing gamma/delta $\mathrm{T}$ cell receptors. Eur J Immunol (1991) 21:173-8. doi:10.1002/eji.1830210126

55. Nelson EL, Kim HT, Mar ND, Goralski TJ, McIntyre BW, Clayberger C, et al. Novel tumor-associated accessory molecules involved in the gamma/ delta cytotoxic T-lymphocyte-Burkitt's lymphoma interaction. Cancer (1995) 75:886-93. doi:10.1002/1097-0142(19950201)75:3<886::AID-CNCR2820750321>3.0.CO;2-G

56. Liu Z, Guo BL, Gehrs BC, Nan L, Lopez RD. Ex vivo expanded human Vgamma9Vdelta2+ gammadelta-T cells mediate innate antitumor activity against human prostate cancer cells in vitro. J Urol (2005) 173:1552-6. doi:10.1097/01.ju.0000154355.45816.0b

57. Siegers GM, Ribot EJ, Keating A, Foster PJ. Extensive expansion of primary human gamma delta $\mathrm{T}$ cells generates cytotoxic effector memory cells that can be labeled with Feraheme for cellular MRI. Cancer Immunol Immunother (2013) 62:571-83. doi:10.1007/s00262-012-1353-y

58. Wang P, Malkovsky M. Different roles of the CD2 and LFA-1 T-cell co-receptors for regulating cytotoxic, proliferative, and cytokine responses of human V gamma 9/V delta $2 \mathrm{~T}$ cells. Mol Med (2000) 6:196-207.

59. Dutta I, Postovit LM, Siegers GM. Apoptosis induced via gamma delta T cell antigen receptor "blocking" antibodies: a cautionary tale. Front Immunol (2017) 8:776. doi:10.3389/fimmu.2017.00776

60. Li H, Pauza CD. HIV envelope-mediated, CCR5/alpha4beta7-dependent killing of CD4-negative gammadelta $\mathrm{T}$ cells which are lost during progression to AIDS. Blood (2011) 118:5824-31. doi:10.1182/blood-2011-05356535

61. Li H, Pauza CD. The alpha4beta7 integrin binds HIV envelope but does not mediate bystander killing of gammadelta T cells. Blood (2012) 120:698-9. doi:10.1182/blood-2012-03-420117

62. Hoshino T, Yamada A, Honda J, Imai Y, Nakao M, Inoue M, et al. Tissuespecific distribution and age-dependent increase of human CD11b+ T cells. J Immunol (1993) 151:2237-46.

63. Wagner C, Hänsch GM, Stegmaier S, Denefleh B, Hug F, Schoels M. The complement receptor 3, CR3 (CD11b/CD18), on T lymphocytes: activation-dependent up-regulation and regulatory function. Eur I Immunol (2001) 31:1173-80. doi:10.1002/1521-4141(200104)31:4<1173::AID-IMMU1173>3.0. CO;2-9

64. Nielsen HV, Christensen JP, Andersson EC, Marker O, Thomsen AR. Expression of type 3 complement receptor on activated CD8+ T cells facilitates homing to inflammatory sites. J Immunol (1994) 153:2021-8.

65. Shimizu Y, Newman W, Gopal TV, Horgan KJ, Graber N, Beall LD, et al. Four molecular pathways of $\mathrm{T}$ cell adhesion to endothelial cells: roles of LFA-1, VCAM-1, and ELAM-1 and changes in pathway hierarchy under different activation conditions. J Cell Biol (1991) 113:1203-12. doi:10.1083/ jcb.113.5.1203

66. Schmeissner PJ, Xie H, Smilenov LB, Shu F, Marcantonio EE. Integrin functions play a key role in the differentiation of thymocytes in vivo. J Immunol (2001) 167:3715-24. doi:10.4049/jimmunol.167.7.3715

67. Wu H, Rodgers JR, Perrard XY, Perrard JL, Prince JE, Abe Y, et al. Deficiency of CD11b or CD11d results in reduced staphylococcal enterotoxin-induced T cell response and T cell phenotypic changes. J Immunol (2004) 173:297-306. doi:10.4049/jimmunol.173.1.297
68. Wohler JE, Smith SS, Zinn KR, Bullard DC, Barnum SR. Gammadelta T cells in EAE: early trafficking events and cytokine requirements. Eur J Immunol (2009) 39:1516-26. doi:10.1002/eji.200839176

69. Bezman NA, Kim CC, Sun JC, Min-Oo G, Hendricks DW, Kamimura Y, et al. Molecular definition of the identity and activation of natural killer cells. Nat Immunol (2012) 13:1000-9. doi:10.1038/ni.2395

70. Maxfield SR, Moulder K, Koning F, Elbe A, Stingl G, Coligan JE, et al. Murine $T$ cells express a cell surface receptor for multiple extracellular matrix proteins. Identification and characterization with monoclonal antibodies. J Exp Med (1989) 169:2173-90. doi:10.1084/jem.169.6.2173

71. Roberts K, Yokoyama WM, Kehn PJ, Shevach EM. The vitronectin receptor serves as an accessory molecule for the activation of a subset of gamma/delta T cells. J Exp Med (1991) 173:231-40. doi:10.1084/jem.173.1.231

72. Wilde DB, Roberts K, Sturmhöfel K, Kikuchi G, Coligan JE, Shevach EM. Mouse autoreactive gamma/delta T cells. I. Functional properties of autoreactive T cell hybridomas. Eur J Immunol (1992) 22:483-9. doi:10.1002/eji. 1830220229

73. Sturmhofel K, Brando C, Martinon F, Shevach EM, Coligan JE. Antigenindependent, integrin-mediated $\mathrm{T}$ cell activation. J Immunol (1995) 154:2104-11.

74. Ruoslahti E, Pierschbacher MD. Arg-Gly-Asp: a versatile cell recognition signal. Cell (1986) 44:517-8. doi:10.1016/0092-8674(86)90259-X

75. Huang S, Endo RI, Nemerow GR. Upregulation of integrins alpha v beta 3 and alpha $\mathrm{v}$ beta 5 on human monocytes and $\mathrm{T}$ lymphocytes facilitates adenovirus-mediated gene delivery. J Virol (1995) 69:2257-63.

76. Guy-Grand D, Vassalli P, Eberl G, Pereira P, Burlen-Defranoux O, Lemaitre F, et al. Origin, trafficking, and intraepithelial fate of gut-tropic T cells. J Exp Med (2013) 210:1839-54. doi:10.1084/jem.20122588

77. Costa MF, Bornstein VU, Candéa AL, Henriques-Pons A, Henriques MG, Penido C. CCL25 induces alpha(4)beta(7) integrin-dependent migration of IL-17(+) gammadelta T lymphocytes during an allergic reaction. Eur J Immunol (2012) 42:1250-60. doi:10.1002/eji.201142021

78. Do JS, Kim S, Keslar K, Jang E, Huang E, Fairchild RL, et al. $\gamma \delta \mathrm{T}$ cells coexpressing gut homing alpha4beta7 and alphaE integrins define a novel subset promoting intestinal inflammation. J Immunol (2017) 198:908-15. doi:10.4049/jimmunol.1601060

79. Edelblum KL, Shen L, Weber CR, Marchiando AM, Clay BS, Wang Y, et al. Dynamic migration of gammadelta intraepithelial lymphocytes requires occludin. Proc Natl Acad Sci U S A (2012) 109:7097-102. doi:10.1073/pnas. 1112519109

80. Edelblum KL, Singh G, Odenwald MA, Lingaraju A, El Bissati K, McLeod R, et al. $\gamma \delta$ Intraepithelial lymphocyte migration limits transepithelial pathogen invasion and systemic disease in mice. Gastroenterology (2015) 148:1417-26. doi:10.1053/j.gastro.2015.02.053

81. Rigo-Adrover MD, Franch A, Castell M, Perez-Cano FJ. Preclinical immunomodulation by the probiotic Bifidobacterium breve M-16V in early life. PLoS One (2016) 11:e0166082. doi:10.1371/journal.pone.0166082

82. Dustin ML. T-cells play the classics with a different spin. Mol Biol Cell (2014) 25:1699-703. doi:10.1091/mbc.E13-11-0636

Conflict of Interest Statement: The author declares that the research was conducted in the absence of any commercial or financial relationships that could be construed as a potential conflict of interest.

Copyright $\odot 2018$ Siegers. This is an open-access article distributed under the terms of the Creative Commons Attribution License (CC BY). The use, distribution or reproduction in other forums is permitted, provided the original author(s) and the copyright owner are credited and that the original publication in this journal is cited, in accordance with accepted academic practice. No use, distribution or reproduction is permitted which does not comply with these terms. 